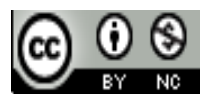

Jurnal Pendidikan Matematika Indonesia is licensed under A Creative Commons Attribution-Non Commercial 4.0 International License.

\title{
The Analysis of Mathematical Creative Thinking SKILlS ANd Self- EFFICACY OG HigH STUDENTS BUILT THROUGH IMPLEMENTATION OF PROBLEM BASED LEARNING AND DISCOVERY LEARNING
}

\author{
Nani Ratnaningsih ${ }^{1)}$ \\ 1) UNSIL, Tasikmalaya, Indonesia \\ E-mail: naniratnaningsih@unsil.ac.id
}

\begin{abstract}
This research implements Problem Based Learning and Discovery Learning model to analysis the increase of mathematical creative thinking skills, mistakes in the process of mathematical creative thinking, and self-efficacy of high school students in Tasikmalaya. The research method used is descriptive, data collection techniques through creative thinking ability tests and questionnaires mathematics self-efficacy. The instruments were previously assessed by experts in mathematics education. Based on the data analysis, it is concluded that the mathematical creative thinking abilities of students through Problem Based Learning is increasing compared to the mathematical creative thinking abilities of students through Discovery Learning. Mistakes students of mathematical creative thinking processes in Problem Based Learning, generally on flexibility and originality indicators. While at Discovery Learning, mistakes students of mathematical creative thinking processes is generally on sensitivity, flexibility and originality indicators. Flexibility is solving the problem with a variety of different ways, but the result is the same, and originality is to solve the problem in its own way does not use a standard formula. Sensitivity is the ability to detect problems. Self-efficacy of students in Problem Based Learning and Discovery Learning are both at high qualifications.
\end{abstract}

Keywords: Problem Based Learning, Discovery Learning, Mathematical Creative Thinking Ability, Self-Efficacy

\section{INTRODUCTION}

Everyone has creative potential that can be developed through a learning process, therefore the mathematical creative thinking skills crucial to students trained, since the basic education up to secondary education (Leung, NCTM, NCTM, 1997, 1991,1989). Even the creative thinking skills need to be given at the level of higher education in order to implement in daily life (Massyrova, 2014). Creativity of students will grow if trained exploration, inquiry, discovery and solve problems (Ruseffendi, 1991). The development of creative thinking is closely related to how to teach teachers, in an atmosphere of non-authoritarian, when students learn on their own initiative, given the confidence to think and dare to put forward new ideas, the creative thinking skills can be developed optimally, in mathematics to encourage creative thinking and higher-level thinking can be done through learning in small groups, presenting non-routine tasks and tasks demanding cognitive and metacognitive strategies and implement approaches scaffolding students (Munandar, Svecova, 2002, 2014)

Based curriculum in 2013, the learning process in schools should be using Problem Based Learning and Discovery Learning. This is because it facilitates student learning exploration, problem solving and build self-efficacy. Problem Based Learning is a learning model that starts from the problem ill-structure associated with everyday life, the student group discussions, and problem solving (Alrahlah, Chang, Fogarty, 2016, 2016, 1997), through the issue the students are trained creative thinking skills and self-efficacy. The learning process through Discovery Learning provides opportunities for students to discover concepts without the help of teachers, and perform observing, grouping, hypothezing, explaining, measuring, and concluding (In'am, 2017). Discovery Learning include: stimulation, problem statement, the data collection, the data processing, verification, and generalization. Teachers 


\section{A - - - Jurnal Pendidikan Matematika Indonesia Volum 2 Nomor 2 bulan September 2017. Page 42-45 p-ISSN: 2477-5967 e-ISSN: 2477-8443}

provide stimulation by asking questions related to the material provided so that exploration, provide the opportunity for students to identify problems and proposed a hypothesis, collect information, process data or information based on the study of theory, test the truth of the hypothesis, and draw conclusions for generalized (In'am, Lingyi, Tompo, 2017, 2010, 2016).

The reality in schools, in general, teachers do not carry out the Problem Based Learning and Discovery Learning, still using frequently asked questions or expository. Therefore, the need to conduct research by applying the Problem Based Learning and Discovery Learning creative thinking so that students skilled mathematics: sensitivity, fluency, flexibility, elaboration, originality (Evans, 1991) and build self-efficacy. Self-efficacy is the perception of the individual's ability to organize and implement actions or individual assessments of ability or competence to perform a task for a purpose, and produce something. Self-efficacy includes three aspects: cognitive, motivational, affective, selection. (Chen, Karbasi, Qudsy 2017, 2016, 2016).

\section{RESEARCH METHOD}

This study is a qualitative research, with its population of students of tenth grade high school in Tasikmalaya. Samples were taken by purposive random sampling. Data collection techniques carry out tests of mathematical ability to think creatively and distributing questionnaires to the students' self efficacy. The research instrument used is a matter of mathematics creative thinking ability tests and questionnaires self efficacy. Problem mathematical creative thinking abilities as much as 5 questions with a maximum score of 20, each of the indicators of the problem include: sensitivity, fluency, flexibility, elaboration, originality. While self-efficacy questionnaire with 22 statements, each statement consists 4 option, includes four indicators: cognitive, motivational, affective, selection. Prior to use, all the research instruments validated by experts to look at the feasibility, then the test is limited, and empirically tested on a sample of students outside, until otherwise decent instruments used for research. Based on the results of validation and test, test questions and the ability to think creatively mathematics self-efficacy questionnaire used as an instrument worthy of research.

\section{RESULTS AND DISCUSSION}

The research was conducted in the tenth grade High School Tasikmalaya, the learning process using a Problem Based Learning and Discovery Learning as much as 6 meetings. Ability to think creatively on Problem Based Learning mathematics obtained a mean of 17.8 while the average mathematical ability of creative thinking on Discovery Learning obtained a mean of 15.3. Based on the results mean it can be concluded that the ability to think creatively mathematics students in Problem Based Learning is better than the ability to think creatively mathematics student at Discovery Learning. This is because in Problem Based Learning learners learn starting from the problems associated with everyday life. By the time students solve problems, learners change of word problems into mathematical models, completes the picture, exploration, must detect or sensitive issues, fix in detail, then finish with a variety of ways. All these activities, train the ability to think sensitivity, fluency, flexibility, elaboration, and originality. While at Discovery Learning Model, the learning process does not start from the problems associated with everyday life, and is therefore less trained students creative thinking abilities mathematics when compared with the Problem Based Learning.

Then analyzed mistakes in solving mathematical creative thinking skills in Problem Based Learning and Discovery Learning. In both groups of students most experienced errors on indicators of flexibility, students are required to solve two different ways with the same result. Students just working with a single procedure, this is because students have not been accustomed to solving problems in two ways. Here is an example of errors students in a matter of flexibility indicators :

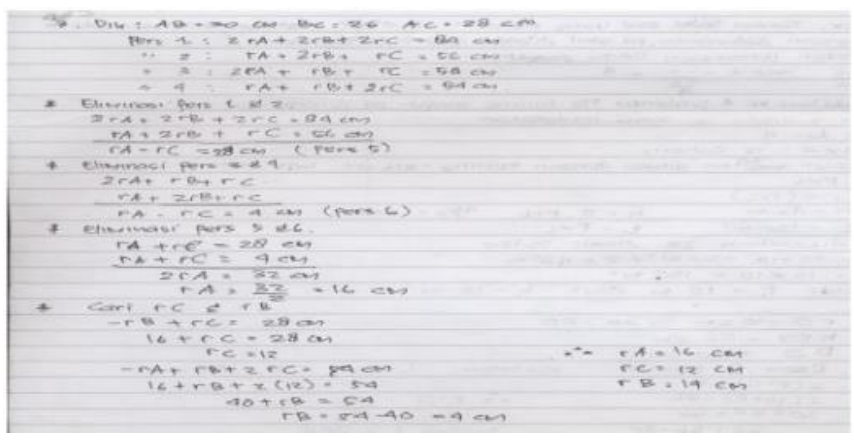

Fig. 1 Example Mistake Problem Solving Students Flexibility

From the student's work, seen students worked only one way, and an error in the settlement process but the final result is true. For about indicators of originality, students solve problems in their own way without using a standard formula. The majority of students in solving one originality indicator. Here is an example of errors students in solving originality:

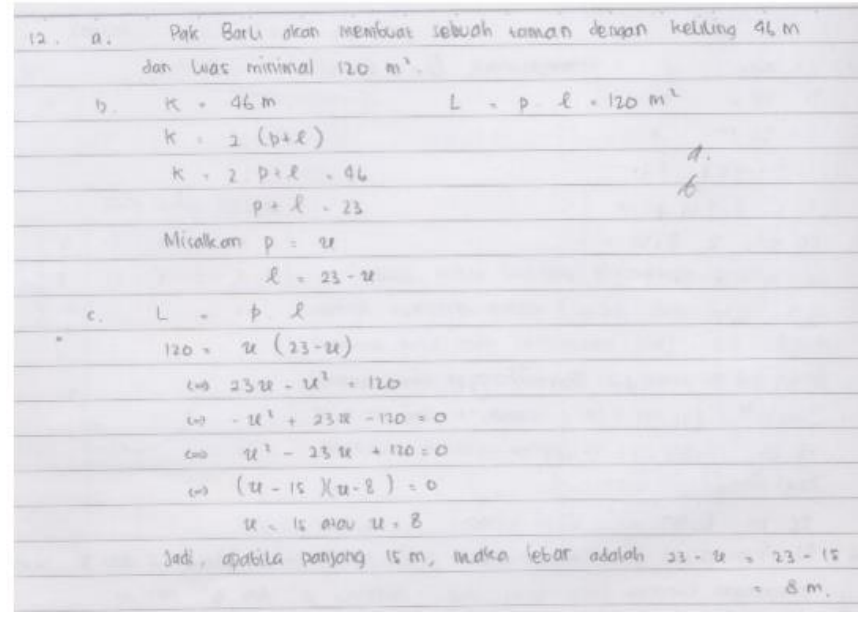

Fig. 2 Example Mistake Problem Solving Students Originality 


\section{- - - Jurnal Pendidikan Matematika Indonesia Volum 2 Nomor 2 bulan September 2017. Page 42-45 p-ISSN: 2477-5967 e-ISSN: 2477-8443}

Noting the mistake, students who use the Problem Based Learning mistake lies in the originality and flexibility indicators. Errors of students who use the Discovery Learning about the same as students who use the Problem Based Learning, but the difference in the Discovery Learning students are generally not sensitive to the issue or have not been able to detect whether the matter can be resolved or not.

Based on the results of mathematical creative thinking ability scores obtained by students in each study group were analyzed at each indicator results are as follows: TABEL 1

The Mean Score Of Mathematical Creative Thinking Skills StUdents ON PROBLEM Based LEARNING (PBL) ANd Discovery LEARNING (DL) VIEWED FROM EACH INDICATOR

\begin{tabular}{|c|c|c|c|}
\hline \multirow[b]{2}{*}{ No } & \multirow{2}{*}{$\begin{array}{c}\text { Mathematical } \\
\text { Critical } \\
\text { Thinking } \\
\text { Ability }\end{array}$} & \multicolumn{2}{|c|}{ Learning } \\
\hline & & PBL & DL \\
\hline 1 & Sensitivity & 3,20 & 2,82 \\
\hline 2 & Flexibility & 2,95 & 2,65 \\
\hline 3 & Fluency & 3,55 & 3,18 \\
\hline 4 & Elaboration & 3,30 & 3,15 \\
\hline 5 & Originality & 2,73 & 2,55 \\
\hline
\end{tabular}

Based on the table, on the matter of indicators fluency and elaboration in both groups of students learning in general do not experience errors even though the results have not been up. This is because, in the matter of indicators fluency students about the responsible men put forward various plans or ideas to complete. Similarly, for the matter of indicators elaboration, students answer questions by completing or developing problems first and then resolved. Based on the above can be drawn the conclusion that students using Problem Based Learning experience errors in answering questions on indicators of flexibility and originality, students using Discovery Learning experience error indicator flexibility, originality, and sensitivity. This is consistent with the results of research (Ratnaningsih, Svecova, 2017, 2014).

Further interviews were conducted on students who make mistakes in answering the question of creative mathematical thinking skills to explore further the obstacles experienced by students. The results of interviews with students obtained information: less careful in reading matter, has not been able to change from word problems into mathematical models, has not been used to work on the problems such as the indicator of sensitivity, flexibility, and originality. In addition, selfefficacy score obtained for each model of learning, on Problem Based Learning self-efficacy is obtained scores of 77.5 and 75.6 for Discovery Learning both at medium qualification. This is because the Model Problem Based Learning and Discovery Learning, learners are equally trained in self-confidence or self-efficacy through group discussions in problem solving, presenting the future, identifying problems or problems at once with this hypothesis, then presented.

\section{CONCLUSIONS}

Based on the results of data analysis and processing research concluded that the ability to think creatively math students by using Problem Based Learning is better than theDiscovery Learning, it is seen from the results of their mean.Students experienced the biggest mistake lies in flexibilityand originality indicator for the use of Problem Based Learning, while those using Discovery Learning students' mistakes lies in the indicator flexibility, sensitivity and originality. Self-efficacy of students who use the Problem Based Learning and Discovery Learning both at medium qualification.

\section{REFERENCES}

Alrahlah, A. (2016). How Effective The Problem Based Learning (PBL) in Dental Education. The Saudi Dental Journal. P. 155-161

Atan, H, Sulaiman, F, \& Idrus, R.M., (2005). The Effectiveness of Problem Based Learning in The Web-Based Environment for TheDelivery of An Undergraduate Physics Course. InternationalEducation Journal. p.430-437

Chang, B.J. (2016). Problem Based Learning in Medical School: A Student's Perspective. Annals of Medicine and Surgery Journal. Elsevier, p.88-89

Chen, H, Dai, J, \& Gao, Y (2017). Measurement Invariance andLatent Mean Differences of The Chinese Version Physical Activity SelfEfficacy Scale Across Gender and Education Levels. Journal of Sport and Health Science xx, p.1-9

Evans, J.R. (1991). Creative Thinking in the Decision and Management Sciences. USA: South-Western Publishing Co

Fogarty, R. (1997). Problem-Based Learning and Other Curriculum Models for the Multiple Intelligences Classroom. Australia: Hawker Brownlow Education.

In'am, A \& Hajar, S (2017). Learning Geometry Through Discovery Learning Using a Scientific Approach. International Journal of Instruction, Vol 10 No. 1 p.55-70

Leung, S.S. \& Silver, E.A. (1997). The Role of Task Format, Mathematics Knowledge, and Creative Thinking on The Arithmetic Problem Posing of Prospective Elementary SchoolTeachers. Mathematics Education Research Journal. Elsevier, Vol 9 No.1 p. 5-24

Lingyi, H (2010). Using GPS to Design Narrative-Centered Environments for Guided Discovery Learning "Facade" a Case Study of a Nonlinear Story. Procedia Social and Behavioral Sciences Journal. Elsevier, p. 4032-4037

Maarif, S. (2016). Improving Junior High School Students' Mathematical Analogical Ability Using Discovery Learning Method. International Journal of Research in Education and Science, Volume 2 Issue 1

Massyrova, et al (2014). Theoretical and Experimental Study of The Concept of The Students Creative Thinking. Procedia Social and Behavioral Sciences Journal. Elsevier, p.445-448

Munandar, U. (2002). Kreativitas dan Keberbakatan. Jakarta: PT Gramedia Pustaka Utama.

National Council of Teachers of Mathematics (1989). Curriculum and Evaluation Standars for Schools Mathematics. Reston, VA: Author

National Council of Teachers of Mathematics (1991). ProfessionalStandards for Teaching Matematics. Reston, VA: Author

Qudsyi, H \& Putri, M.I (2016). Self-Efficacy and Anxiety of National Examination Among High School Students. Procedia Social and Behavioral Sciences Journal. Elsevier, p. 268-275

Ruseffendi, E.T. (1991). Pengantar kepada Membantu Guru Mengembangkan Kompetensinya dalam Pengajaran Matematika untuk Meningkatkan CBSA. Bandung: Tarsito.

Ratnaningsih, N \& Patmawati, H (2015). Developing Character Based Interactive Learning Media to Facilitate Students' selfLearning of Capita Selecta Mathematics (A Research on Mathematical Critical and Creative Thinking Skills of Mathematics Department Students of Teachers Training and Education Faculty of Siliwangi University). Prosiding Seminar Internasional ICTTE FKIP UNS

Ratnaningsih, N (2016). Development Interactive Learning Media to Excavate Ability Mathematical Creative Thinking Students. Prosiding Seminar Internasional FKIP UNY

Svecova, R, Rumanova, L, \& Pavlovicova, G (2014). Support ofipil's Creative Thinking in Mathematics Educations. ProcediaSocial and Behavioral Sciences Journal. Elsevier, p.1715-1719 
Tompo, A, Ahmad, A, \& Muris, M (2016). The Development ofDiscoveryInquiry Learning Model to Reduce The Science Misconceptions of Junior High School Students.International Journal of Environmental \& Science Education.Vol.11 No.12 p.5676-5686 